\title{
Economic Sanctions, Transnational Terrorism, and the Incentive to Misrepresent
}

\author{
Navin A. Bapat, University of North Carolina, Chapel Hill \\ Luis De la Calle, Centro de Investigación y Docencia Económicas \\ Kaisa H. Hinkkainen, University of Lincoln \\ Elena V. McLean, State University of New York at Buffalo
}

Can economic sanctions combat transnational terrorism effectively? Policy makers argue that sanctions can deter state sponsorship but are counterproductive against hosts of transnational terrorists. However, recent cases indicate that governments are often uncertain if foreign states are truly sponsors versus hosts and cannot perfectly determine the type of foreign support terrorists are receiving. We argue that this uncertainty, coupled with the proposed strategy of punishing sponsors while cooperating with hosts, creates incentives for sponsors to misrepresent themselves as host states while continuing their support for terrorists. We demonstrate that in this environment of uncertainty, governments rely on information regarding the state capacity of supporting states to deduce their relationship with terrorists. Consequently, governments are more likely to impose sanctions against foreign states with intermediate levels of state capacity but are less likely to impose sanctions against failing or stronger states.

A fter 9/11, Gary Hufbauer, a prominent sanctions researcher, declared that sanctions could play an effective supporting role in the "war on terror" (Hufbauer 2001). Sanctions could be used as both a carrot, in that the United States could offer to remove sanctions on regimes in exchange for their cooperation, and a stick, where the United States could impose sanctions to punish state sponsors. However, according to the recently updated Threat and Imposition of Sanctions (TIES) data, senders threatened to impose sanctions on hosts of transnational terrorists in only 25 cases in the period 1945-2005 and imposed sanctions 15 times. ${ }^{1}$ Just four of the 15 cases yielded a positive outcome, and each of these cases involved a threat or use of military force in addition to the imposition of sanctions. These patterns raise the question: Can economic sanctions ever be effective tools in combating foreign support for transnational terrorists?
This study develops a theoretical and empirical analysis to identify the conditions under which states impose sanctions against foreign supporters of transnational terrorist groups. Much of the current literature assumes that governments are capable of distinguishing state sponsors from host states and can therefore punish sponsors using sanctions while cooperating with host states. In some cases, such as Libya's support for Abu Nidal or Somalia's hosting of al Shabaab, the relationship between the supporting state and the group is easy to determine. However, governments are often uncertain whether a supporting state is actually a sponsor or a host (Byman 2005b; Findley, Piazza, and Young 2012). Consider, for instance, the relationship between Pakistan and al Qaeda. While the government of this country denied its support for the terrorist group, recent information, including some of the unauthorized infor-

Alphabetical ordering indicates equal contributions. Navin A. Bapat (bapat@unc.edu) is at the University of North Carolina, Chapel Hill, 304 Hamilton Hall, Chapel Hill, NC 27599-3625. Luis De la Calle (Luis.delacalle@cide.edu) is at the Centro de Investigación y Docencia Económicas, Carretera Mexico-Toluca 3655, Lomas de Santa Fe, Mexico City 01210. Kaisa H. Hinkkainen (khinkkainen@lincoln.ac.uk) is at the University of Lincoln, Baryford Pool, Lincoln LN67TS United Kingdom. Elena V. McLean (elenamcl@buffalo.edu) is at SUNY Buffalo, 520 Park Hall, Buffalo, NY 14260.

Support for this research was provided by National Science Foundation grant SES 0921264. Data and supporting materials necessary to reproduce the numerical results in the article are available in the JOP Dataverse (https://dataverse.harvard.edu/dataverse/jop). An online appendix with supplementary material is available at http://dx.doi.org/10.1086/683257.

1. TIES data, version 4.0, are available at http://www.unc.edu/ bapat/TIES.htm (accessed September 25, 2015).

The Journal of Politics, volume 78, number 1. Published online September 30, 2015. http://dx.doi.org/10.1086/683257

(C) 2015 by the Southern Political Science Association. All rights reserved. 0022-3816/2016/7801-0017\$10.00 
mation reported by Wikileaks, indicates that the government took steps beyond simply turning a blind eye to al Qaeda's activities. In particular, Pakistan appears to have frequently informed al Qaeda operatives about pending US drone strikes and intelligence collection efforts, thereby allowing al Qaeda to survive American counterterrorist efforts. Furthermore, intelligence reports indicate that the Pakistani ISI had considerably more power over terrorist operations in its border areas than it let on: the ISI directly assisted in smuggling operatives across the Afghan border and sheltering them, and chose not to arrest al Qaeda and Haqqani operatives in the border region. Taken together, this information paints a picture of a Pakistani state that could control where al Qaeda could operate and the group's use of terrorist violence in Afghanistan. Therefore, contrary to Pakistan's assurances that it was fighting to curb al Qaeda's terrorism, there is now evidence of direct involvement and support.

Using a game theoretic model, we capture these two possible types of relationships and argue that this uncertainty encourages true state sponsors to misrepresent themselves as host states. In response to the uncertainty, governments evaluate the state capacity of supporting states to determine the nature of their relationship with terrorists. We demonstrate that governments are unlikely to impose sanctions against foreign supporters with weak state capacity, given that such supporters are unlikely to have sufficient resources to sponsor terrorists and are therefore likely to be hosts. Governments are also unlikely to impose sanctions against foreign supporters with high state capacity. Although these states are more likely to be sponsors than hosts, high-capacity states also tend to be more valuable economic partners, thereby making sanction costs prohibitive. However, while governments do not sanction states with weak state capacity and cannot sanction states with high state capacity, governments may sanction foreign supporters with intermediate levels of state capacity. These types of foreign supporters (such as Syria and Pakistan) maintain enough capacity to effectively sponsor terrorists, but not so much that they can be identified as obvious sponsors. Since these foreign supporters may be sponsors masquerading as hosts and since the costs of sanctioning these states are not excessive, governments are more likely to impose sanctions against intermediate-capacity states. We conclude by testing this hypothesis using the TIES data along with the Global Terrorism Database (GTD). ${ }^{2}$

2. The GTD, sponsored by the National Consortium for the Study of Terrorism and Responses to Terrorism, is available at http://www.start .umd.edu/gtd (accessed July 16, 2015).

\section{ECONOMIC SANCTIONS AND THEIR EFFECT ON FOREIGN SUPPORT FOR TERRORISM}

A sanction is defined as an action one or more states take to limit their economic relations with a target state in an effort to persuade the target to change one or more of its policies (Hufbauer et al. 2007; Morgan, Bapat, and Krustev 2009). Theoretically, free economic exchanges produce a surplus in goods and services, which the countries involved in the trading relationship then distribute between them. However, the use of sanctions and the resulting market imperfections diminish this surplus by impeding the free exchange between individuals and firms within the sender and target countries (DeGennaro 2005; Greenwald and Stiglitz 1993). Although the gains from trade benefit both the sender and the target, the sender may threaten to undermine the economic relationship to extract policy concessions (Drezner 2003; Wagner 1988). Sanctions disputes are therefore often conceptualized as a bargaining problem: the imposition of sanctions is assumed to be ex post inefficient, meaning that since sanctions reduce the gains from trade, both the sender and the target should prefer some agreement prior to their imposition.

Early sanctions studies based on the Hufbauer et al. (2007) data set initially found that these instruments were ineffective and provided little in terms of extracting policy concessions (Drury 1998; Morgan and Schwebach 1997; Pape 1997). Recent theoretical and empirical work, however, points out that these studies suffered from selection bias because they examined only cases in which sanctions were actually imposed (Drezner 2003; Lacy and Niou 2004; Morgan and Miers 1999; Nooruddin 2002; Smith 1995). An important conclusion was that if target states refused to acquiesce to sanctions, they had likely already made a cost/ benefit calculation and decided that they preferred suffering sanctions to changing their policies following imposition. ${ }^{3}$ The implication of these studies was that sanctions could prove to be more effective if analysts examined sanction threats in addition to impositions. A significant number of studies now demonstrate that the probability of sanction success improves if sanctions are relatively costly to the target and if the sanctions effort is multilateral or institutionalized (Allen 2005; Bapat and Morgan 2009; McLean and Whang 2010). These findings further indicate that sanction threats are more effective if they are issued through international institutions, aim at democratic targets, and promise to suspend a significant volume of trade (Bapat et al. 2013).

3. Also, note that low instrumental effectiveness does not mean that sanctions cannot impose severe economic costs on the target country. Some estimates indicate that target costs can reach double digits as a share of the target's GNP (Hufbauer et al. 2007, 105). 
None of these studies, however, address the question of sanctions' utility in assisting governments to combat transnational terrorism. During the Cold War, governments imposed sanctions against other states that were accused of actively sponsoring terrorism by providing terrorist organizations with materials, intelligence, weapons, and fighters (Bapat 2012; Byman 2005a; Carter 2015; Conrad 2011). To deal with this problem, according to existing research, governments used the threat of military force to compel sponsors into disarming their terrorists. In practice, however, military strikes against terrorist targets within sanctuary states are often unsuccessful and typically result in larger, more expanded wars. Since this option is also quite costly, governments facing problems of transnational terrorism might consider substituting military force with alternatives - one of which is sanctions. Sanctions could directly harm the sponsor's economy, which in turn could compel it to abandon its support for terrorism.

However, after the end of the Cold War, transnational terrorists increasingly conducted operations without sponsorship using the territories of host states (Byman 2005a, 2005b; Byman et al. 2001; Carter 2015). Unlike sponsors that directly aided terrorist groups, host governments are often unstable or lack the capacity to control their populations (Collier and Hoeffler 2005; Fearon and Laitin 2003; Hegre and Sambanis 2006). In these cases, terrorists operate from an area in the host state but are autonomous from the host government, and hence analysts concluded that aggressive tactics such as military strikes or economic sanctions could produce adverse consequences. Specifically, Marinov (2005) and McGillivray and Stam (2004) show that sanctions can increase the probability of leadership turnover within target states. The research on political transitions indicates that abrupt leadership changes combined with increased economic problems often produce political instability, thereby strengthening the very terrorists the sender seeks to disarm (Aksoy and Carter 2012; Fearon 2004). Sanctions in particular could weaken the foundations of the host's economy, which in turn might exacerbate political instability and increase the popularity of antigovernment actors, including terrorist groups (Enders and Hoover 2012; Weinstein 2007). Harming the host's economy with sanctions may therefore produce a backlash that could lead to the rise of an opposition party that is sympathetic to terrorists' agenda or allow the group itself to seize power.

Given that punitive measures against host states appear self-defeating, policy analysts warned against any action that might jeopardize the target's counterterrorism efforts (Carter 2015; Schultz 2010). Instead, governments should prefer strengthening the host's capacity to enable it to disarm the terrorists on its own. To do so, governments could increase the host's access to capital and resources, which could be accomplished by expanding international trade and investment. Theoretically, governments' decision to increase economic ties with a host should produce more efficient markets, which in turn could indirectly allow the host to gain greater resources to fight terrorism (Li and Schaub 2004). This cooperation should make both sides better off, since both enjoy the benefits of increased economic exchanges and improved counterterrorism cooperation.

We therefore see that the optimal policy for governments facing transnational terrorist groups is to punish state sponsors with sanctions while expanding economic ties with host states. However, this strategy assumes that governments can perfectly distinguish between the two types of states. Recent studies, however, indicate that drawing this distinction is often quite difficult because of efforts by state sponsors to mask their support of terrorist groups. To illustrate, consider the case of Pakistani cooperation with the United States in the "war on terror." The United States issued a threat following the 9/11 attacks: Pakistan could cooperate with the United States in exchange for significant economic and military ties, or it would face isolation and the American military. Pakistani leader Pervez Musharraf pledged to cooperate with American efforts against the Taliban and al Qaeda. The United States used bases within Pakistan to punish the Taliban in Afghanistan, and the Pakistani military began to attack Taliban strongholds directly. Despite these initial successes, the Taliban regrouped in 2004 and began staging attacks from Pakistan's Federally Administrated Tribal Areas (FATA). Analysts offered two explanations for the Taliban's resurgence. One possibility was that Pakistan's government faced incredible strain, and the United States needed to provide even greater support for Musharraf's efforts to disarm the militants. Another possibility was that Musharraf was using a portion of US resources to fund terrorist violence to achieve the goal of keeping Afghanistan weak. Although recent information provides some evidence in favor of the latter argument, the fact remains that thousands of Pakistani troops were killed fighting the Taliban, and Musharraf faced multiple assassination attempts. These observations provide evidence in favor of the former argument. This contradictory evidence illustrates that governments operate in an environment of significant uncertainty in examining the relationship between terrorists and their home states.

This problem raises a key question: how can governments distinguish between sponsor and host states in the environment of uncertainty? One of the key pieces of information governments use to make this determination is the state capacity of supporting states. For example, given its extensive Soviet support and military state, it seems unlikely 


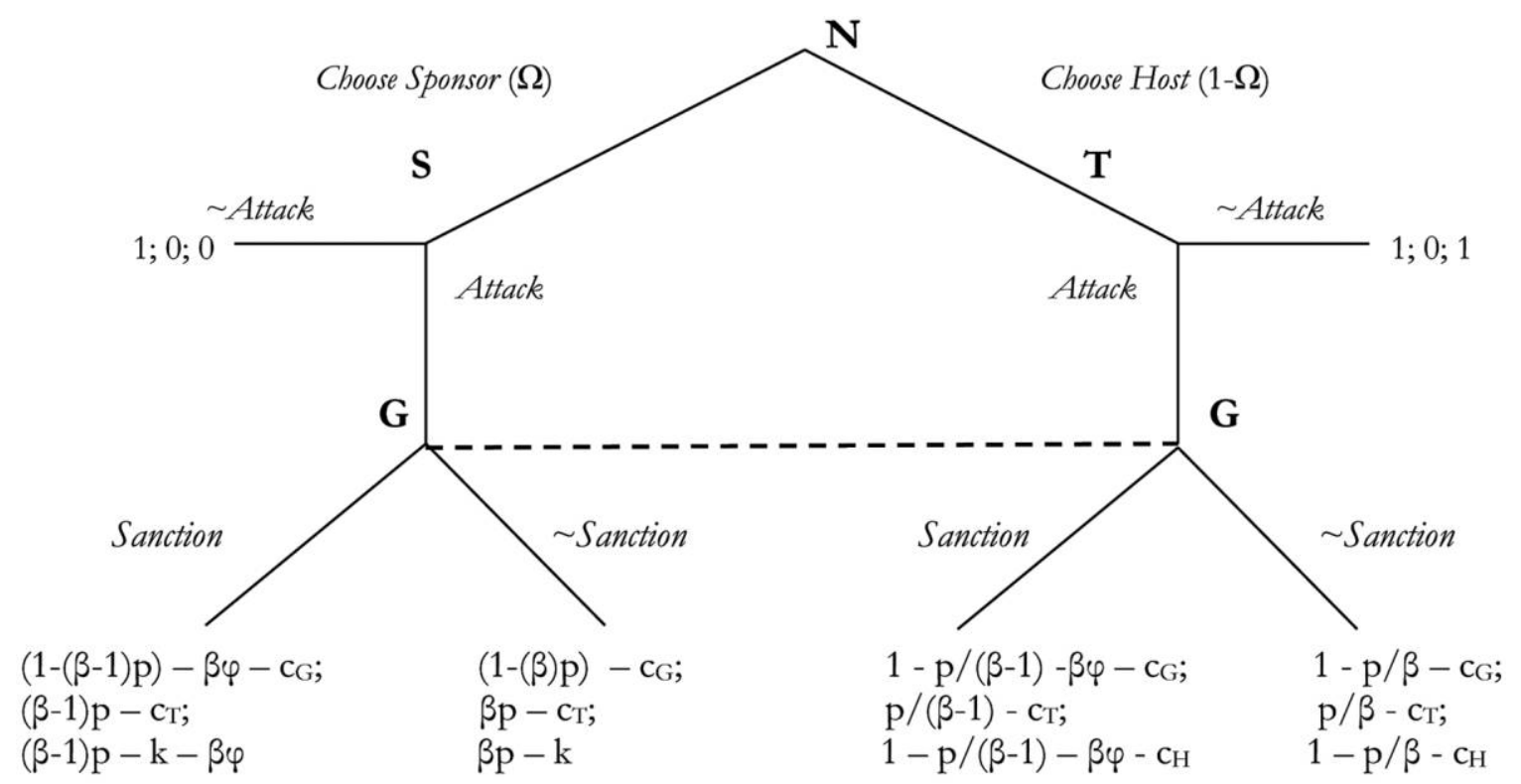

Figure 1. Transnational terrorism game

that the Red Army Faction operated without some assistance from the East German state. In an opposite case, it appears less likely that Joseph Kabila's government in the Democratic Republic of the Congo (DRC) is actively sponsoring Hutu militias against Rwanda, given the DRC's low military power and inability to control much of its own territory. The more likely explanation for the continued existence of Hutu militias is that the DRC simply lacks the capacity to disarm these groups. These cases suggest that governments facing transnational terrorism can make inferences by examining the supporter's state capacity. However, these two cases are relatively extreme examples, and many others are less obvious. It is not necessarily clear how much control Pakistan, Syria, Iran, Venezuela, and Sudan have over their territories. While each of these countries is an alleged supporter of terrorists, it is not obvious if this support is direct sponsorship. This uncertainty creates a risk of making a mistake in adopting either the punitive policy of sanctions or the cooperative policy of increasing economic assistance. These mistakes may be quite costly, as providing economic support to a sponsor is likely to strengthen terrorists. On the other hand, punishing a host reduces its capacity, thereby also strengthening terrorist groups. We now turn to the formal model to identify when governments respond to this uncertainty by imposing economic sanctions.

\section{MODEL}

Figure 1 presents a stylized model of a conflict between a government $G$ and a transnational terrorist group $T$ operating from a foreign state that is either a state sponsor $(S)$ or a host $(H){ }^{4}$ The conflict between $G$ and $T$ is over some general political issue, such as the level of political autonomy in a particular region, the number of representatives from $T$ 's preferred party in the national legislature, or an overthrow of the entire governing system. The group $T$ stages terrorist attacks in an effort to compel $G$ into revising the status quo in $T$ 's favor. These attacks may include bombing to sabotage parts of $G$ 's economy, inciting riots and mobilizing students at $G$ s university campuses, kidnapping government officials, or intimidating the population into supporting political changes.

Table 1 presents each of the model's parameters and their definitions. Let us assume that the issue in dispute is indivisible and that $T$ 's violence compels $G$ into making $T$ 's desired political changes with probability $p$ but fails to do so with the corresponding probability $1-p \cdot{ }^{5}$ Both players pay some cost for fighting: $\mathcal{c}_{(G, T)} \in[0,1]$. If $G$ prevents $T$ from accomplishing its objectives, $G$ receives a payoff of 1 while $T$ receives a payoff of 0 . On the other hand, if $T$ succeeds in accomplishing its objectives, $G$ receives a payoff of 0 , whereas $T$ receives a payoff of 1 .

Government $G$ is uncertain if the foreign state is a sponsor or a host state at the start of the game. We represent $G$ 's prior belief that the foreign state is a sponsor $(S)$ as $\Omega$ and $G$ 's prior belief that the foreign state is a host $(H)$ with the corresponding probability $1-\Omega{ }^{6}$ There are two key differ-

\footnotetext{
4. Assume that the players are risk neutral.

5. Since $p$ is a probability, $p \in[0,1]$.

6. Government $G$ 's prior belief $\Omega$ is exogenous. Assume that $\Omega \in[0,1]$ since it is the probability that nature draws $S$.
} 


\begin{tabular}{ll} 
Parameter & \multicolumn{1}{c}{ Interpretation } \\
\hline$\Omega$ & G's prior belief that foreign state is a sponsor $(S)$ \\
$1-\Omega$ & $G$ 's prior belief that $T$ is autonomous and that foreign state is a host $(H)$ \\
$p$ & Baseline probability $T$ achieves its objectives \\
$1-p$ & Baseline probability $G$ disarms $T$ \\
$c_{(G, T)}$ & Cost for fighting in terrorist campaign \\
$k$ & Cost to $S$ for sponsoring $T$ \\
$\beta$ & Foreign state's capacity \\
$\varphi$ & Value of economic transactions between $G$ and foreign state
\end{tabular}

Note. It is assumed that none of the parameters fall below a value of 0 or can exceed a value of 1 , with the exception of $\beta \in[1,2]$.

ences between the two types. First, sponsors prefer outcomes in which $T$ succeeds in revising the status quo, whereas hosts prefer to maintain the status quo that is in G's favor. ${ }^{7}$ Second, if the terrorists operate from the host state $H, T$ maintains autonomy over its decision making. Therefore, $T$ begins the game with its decision whether to attack $G$ if nature chooses $H(1-\Omega)$. On the other hand, if terrorists operate from sponsor $S$, the sponsor initially maintains control over $T$. Therefore, if nature selects a sponsor $(\Omega), S$ decides if the terrorists attack $G$ or not. Should either $S$ or $T$ decide to attack, $G$ observes that terrorist attacks took place but cannot perfectly distinguish between state-sponsored attacks and attacks by autonomous groups from hosts. The information set indicates that $G$ is uncertain if the foreign state is a sponsor that is antagonistic to its interests or a host that is supportive of its interests. Substantively, this represents a strategic situation similar to the one that the United States faced in the early to mid-2000s in dealing with Musharraf's Pakistan. In this case, the United States could not perfectly determine if Pakistan was an ally in the war on terror or if Pakistan was duplicitous and supported the Taliban and al Qaeda.

The model assumes that the foreign state has some ability to increase T's fighting capability if it is a sponsor and some ability to undermine $T$ 's fighting capability if it is a host. The foreign state's ability to increase or undermine $T$ is a function of its state capacity, represented formally by the parameter $\beta \in[1,2]$. The capacity $\beta \rightarrow 1$ in cases in which the foreign supporter exhibits low state capacity (such as Yemen), and $\beta \rightarrow 2$ if the foreign supporter is relatively wealthy and powerful (such as Saudi Arabia). This

7. This indicates that $u_{S}=1$ if $T$ prevails and $u_{S}=0$ if $G$ wins, and vice versa for the host $H$. indicates that relatively powerful foreign supporters are better able to influence $T$ 's fighting ability than weaker ones. ${ }^{8}$ To capture the effect of sponsorship, assume that state support increases $T$ 's military capability from $p$ to $\beta p .{ }^{9}$ For example, both US Secretary of Defense Leon Panetta and Admiral Michael Mullen charged in 2011 that Pakistani sponsorship was improving the Haqqani network's ability to carry out attacks in Afghanistan. On the other hand, if the foreign supporter is a host, it can hinder T's ability to engage in its conflict against $G$ by closing camps, policing the border, monitoring finances, and so forth. We therefore assume that $T$ 's ability to operate from a hostile host state falls from $p$ to $p / \beta$. For example, following the December 2001 bombings of the Indian Parliament building in New Delhi, Musharraf vowed to crack down on all militants in Pakistan and made numerous arrests, which likely decreased the fighting capacity of Kashmiri terrorists operating against India. This supports the assumption that hosts can undermine terrorists' ability to accomplish their objectives if hosts choose to cooperate, whereas sponsors can increase the probability that terrorists will succeed by assisting the group.

8. Formally, since $\beta \geq 1$, it must be true that $\beta p \geq p$. Since $\beta p$ is a probability, assume that if $\beta p>1, \beta p=1$. We assume $\beta \leq 2$ to avoid cases in which sponsors can improve the power of terrorists to such an extent that they are impossible to disarm. The ability of terrorists to strengthen with sponsorship is likely partially endogenous to the group's capability without assistance. It is also quite rare for even the most powerful sponsors to more than double the fighting power of terrorist organizations. These restrictions are captured by the limits on $\beta$.

9. Empirically, not all forms of sponsorship require extensive resources. However, sponsors are better able to influence terrorist groups' success with greater resources, which are more likely to be available to high-capacity states. We therefore assume that the group's ability to succeed increases to a greater extent if it is supported by a high-capacity state. For more justification of this assumption, see Byman (2005a). 
Nature begins the game by selecting either a sponsor with probability $\Omega$ or a host with probability $1-\Omega .{ }^{10}$ If nature selects a sponsor, $S$ chooses to sponsor terrorism against $G$ or to accept the status quo, which ends the game. Should $S$ sponsor terrorism and play Attack, $S$ expends some military resources to $T$ as $k \in[\underline{k}, \bar{k}]$, which may represent the capital needed to finance $T$ 's operations, the weaponry delivered to $T$ 's members, or the cost of providing intelligence and/or bases to the group. ${ }^{11}$ Lower levels of support, such as political inspiration or intelligence sharing, correspond to lower values of $k$, whereas more critical levels of support, such as the provision of bases or fighters, correspond to higher values of $k^{12}$ If nature chooses $H$ instead (with probability $1-\Omega$ ), the terrorists $T$ choose to either attack $G$ or refrain from engaging in violence. If the group chooses not to attack, the game ends with the status quo intact. If the group instead resorts to terrorism, the game continues.

If either $S$ or $T$ attacks, $G$ observes terrorist activity emanating from within the foreign state's territory. Next $G$ decides whether to punish the foreign state by imposing sanctions and severing economic transactions or to behave in a more cooperative fashion by maintaining economic links. ${ }^{13}$ The decision to sanction is costly for both the government $G$ and the foreign state. Formally, $S$ or $H$ pays a cost $\varphi$ while $G$ pays a cost $-\beta \varphi$ if sanctions are imposed, where $\varphi \in[0, \bar{\varphi}]$ represents the size of the economic relationship between the

10. Since $\Omega$ represents the probability that nature chooses $S$, assume that $\Omega \in[0,1]$. Theoretically, it is possible that this relationship is dynamic and that a sponsor at time $t$ may abandon terrorists at time $t+1$, thereby switching its type to a host. However, for simplicity, we restrict the game to one round. This is appropriate given our substantive question, which is whether a government imposes sanctions on the foreign state at time $t$.

11. The term $k$ is an exogenous parameter.

12. Byman (2005a) and Byman et al. (2001) discuss the variation in the types of sponsorship.

13. This dilemma resembles the one described by Kydd and Walter (2002), where governments attempt to determine if moderates are exerting enough effort to control extremists in their organization from engaging in violence. However, this model differs from Kydd and Walter's in that the sponsor alone determines whether the terrorists attack if nature draws this type of foreign supporter. We adopt this setup partially to simplify the model but also because a more complex version in which the sponsor chooses to encourage or curb terrorist violence reduces to our current setup. If the sponsor restrains the group, the game ends, as it does in our version when $S$ chooses $\sim$ Attack. If the sponsor allows the terrorists to attack and the group attacks, this is equivalent to $S$ playing Attack. The only set of cases not captured by our model occur when the sponsor allows terrorists to attack but they refuse. These cases are less theoretically interesting and are highly unusual empirically. We therefore see that aside from these rare cases, the more complicated model reduces to our simpler game. two states. ${ }^{14}$ Values of $\varphi \rightarrow \bar{\varphi}$ indicate increasing levels of economic transactions with the foreign state, whereas values of $\varphi \rightarrow 0$ indicate that economic transactions between $G$ and the foreign state are relatively modest, and hence sanctions are less damaging. The effects of severing the economic transactions between $G$ and the foreign state are multiplied by the $\beta$ parameter, which indicates that economic exchanges are more valuable to the government if the foreign state has a greater capacity. Substantively, this suggests that commerce between the two states is more lucrative if the foreign state has an effective police force to protect property rights and multinationals, developed infrastructure, and a more educated workforce. On the other hand, if the foreign state is a low-capacity state with rampant corruption, poor roads and bridges, and a low-skill workforce, the value of the economic relationship diminishes. ${ }^{15}$ Representing the loss of economic transactions resulting from sanctions as $-\beta \varphi$ captures the difference in the value of economic exchanges from different types of foreign states.

In addition to imposing economic damage on both sides, sanctions harm the ability of both sponsors and hosts to use their resources to influence the terrorist campaign. Formally, assume that if sanctions are imposed, terrorists' ability to accomplish their objectives from host states increases from $p / \beta$ to $p /(\beta-1)$. On the other hand, if the foreign state is a sponsor, severing economic transactions may diminish terrorists' effectiveness. If sanctions are imposed on $S, T$ 's probability of success decreases from $\beta p$ to $(\beta-1)$ $p .{ }^{16}$ Sanctions therefore have different effects on $T$ 's ability to operate given the type of foreign supporter. Substantively, this suggests that cutting a sponsor's oil revenues will reduce its resources to fund terrorism; however, cutting a host's oil revenues will reduce its resources to monitor terrorist activity and arrest suspects. Therefore, sanctions are beneficial to senders when directed at sponsors but are counterproductive when imposed against host states. Once $G$ makes its choice of whether to impose sanctions or not, nature next determines if $T$ succeeds in compelling $G$ to

14. Assume that $\bar{\varphi} \leq 1$. While we examined a version of the model in which $\varphi$ was the product of endogenous bargaining between $G$ and the foreign state, we found that substantive empirical predictions of the model did not change if $\varphi$ was endogenous, and therefore, we opted for the simpler version of the model.

15. This assumption is based on empirical work suggesting that interstate commerce is more prevalent in high-income countries vs. developing ones. See World Bank (2010).

16. We see that this is true since $\beta p>(\beta-1) p$ simplifies to $\beta p>\beta p-$ $p$, which simplifies to $0>-p$. This is always true if $p>0$. Substantively, this indicates that even a minor sanction can diminish state sponsors' ability to strengthen terrorist groups. 
alter the disputed policy or if $G$ suppresses $T$ and maintains G's preferred status quo.

\section{SOLUTION}

The game is solved using the perfect Bayesian solution concept. ${ }^{17}$ We begin by considering G's decision. Since sponsors use economic transactions to fuel the terrorists, $G$ enhances its counterterrorism effort by imposing sanctions against sponsors. On the other hand, since sanctions harm hosts' ability to fight terrorists, governments should prefer avoiding sanctions when facing host states. Therefore, if $G$ refuses to impose sanctions but the foreign state is actually a sponsor, $G$ undermines its own counterterrorism effort. However, $G$ also undermines its counterterrorism effort if it imposes sanctions and the foreign state is a host. We therefore see the crux of the government's key decision problem: failing to impose sanctions against a sponsor harms counterterrorism, but imposing sanctions against hosts also undermines counterterrorism.

Government $G$ updates its belief about the foreign state's type after observing terrorist attacks. The attacks represent a strategic choice made by either the sponsor or the terrorists themselves. Figure 2 presents a set of cut points identifying the foreign state's strategic behavior as a function of the foreign state's capacity $(\beta) .{ }^{18}$ At the left-hand side of the plot where $\beta<k / p$, governments know that weaker sponsors have a dominant strategy to play $\sim$ Attack. Foreign states that are poorer with weaker militaries are less able to strengthen terrorists significantly with sponsorship. Formally, if $\beta$ is low, an increase from T's baseline fighting power of $p$ to $\beta p$ is likely to be relatively small. Since sponsorship is costly $(k)$ and weaker foreign states cannot enhance terrorists' fighting power significantly, governments know that weaker states are more likely to be hosts rather than sponsors. Several empirical studies support the model's conclusion that terrorists operate with autonomy from relatively weak states (Piazza 2008; Salehyan 2009). If these

17. The complete formal solution is in the appendix.

18. We demonstrate that $G$ imposes sanctions in mixed strategies against foreign states with intermediate levels of capacity as part of a semiseparating equilibrium $(k / p<\beta<p / \varphi)$. Let $\Omega^{*}$ (formally defined in eq. [1]) represent the belief that $G$ is indifferent between playing Sanction vs. $\sim$ Sanction. The solid line maps the probability that $G$ imposes sanctions in mixed strategies when $\Omega=.95$. This represents cases in which $\Omega>\Omega^{*}$ and $1.167 \leq \beta<1.45884$. In these cases, $G$ has a very strong prior that the foreign state is a sponsor and imposes sanctions with probability $q=(\beta p-$ $k) /(\varphi+p)$. The dashed line represents the probability that $G$ imposes sanctions when $\Omega=.45$, which represents cases in which $\Omega^{*} \geq \Omega$ and $1.2 \leq$ $\beta<1.67$. In these cases, $G$ has a weaker prior that the foreign state is a sponsor and imposes sanctions with probability $j=\left[(\beta-1)\left(\beta c_{T}-p\right)\right] / p$.

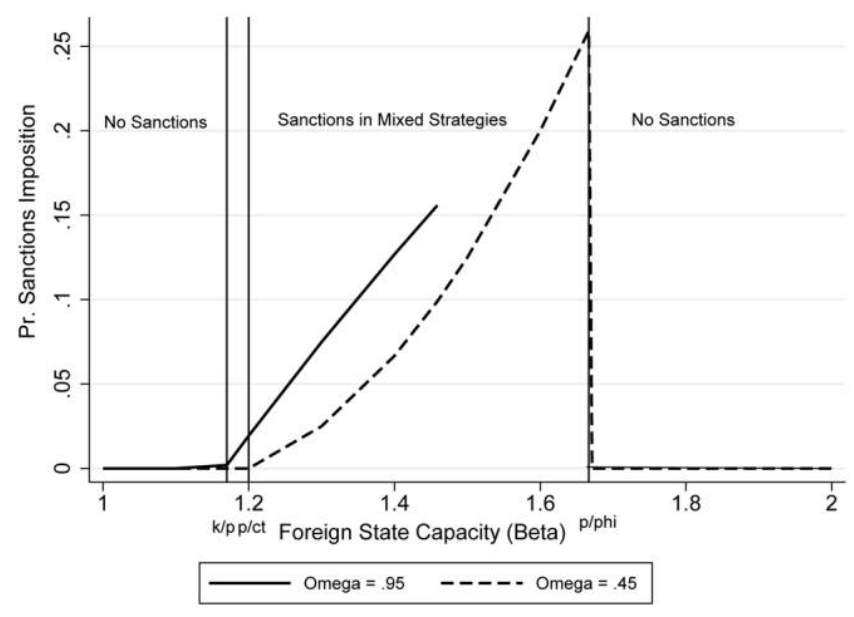

Figure 2. Probability that $G$ imposes sanctions following observation of terrorist violence holding: $p=.3, \varphi=.18, c_{T}=.25, k=.35$.

states appear to lack the ability to control their territories, it makes sense that they are also unlikely to have the resources needed to strengthen terrorists. The government's optimal strategy is therefore to avoid imposing sanctions and to maintain cooperation with the host.

Proposition 1. For sufficiently low-capacity foreign states $(\beta<k / p)$, no sanctions occur and the following strategies and beliefs constitute a perfect Bayesian equilibrium:

1. Sponsor: $\sim$ Attack.

2. Terrorists: Attack.

3. Government: $\sim$ Sanction.

4. Beliefs: $\operatorname{Pr}\{\Omega \mid$ Attack $\}=0 \& \operatorname{Pr}\{\Omega \mid \sim$ Attack $\}=1$.

Proof. See the appendix, available online.

We see that the opposite is true in cases on the righthand side of figure 2, where the foreign supporter is relatively strong $(\beta>p / \varphi)$. Terrorists recognize that these powerful host states will alter the balance of power in favor of the government. If the host reduces the probability that terrorists succeed and conducting terrorist campaigns is costly, ${ }^{19}$ we would expect terrorists to suspend their campaigns when they operate from powerful hosts. Empirically, this means that governments should not observe autonomous terrorists staging attacks from stronger hosts. If a foreign state is powerful enough to deter terrorists but the government observes terrorism, the government will update that the foreign state is a sponsor. Yet, even if the

19. If $\beta \rightarrow 2$, the probability of terrorist success decreases from $p$ to $p /$ 2 , which is a $50 \%$ reduction. Terrorists must pay $c_{T}$ if they fight. 
government observes terrorism, it may still avoid imposing sanctions against high-capacity states. Although sanctions improve the government's counterterrorism effort, highcapacity states are more likely to have larger markets for exports, better technology, and deeper capital markets. The government may therefore harm its own economy by imposing sanctions against such states, even if it believes that these states are sponsoring terrorism. Therefore, if the foreign state's capacity is relatively greater, governments may refrain from imposing sanctions if the benefit of the economic relationship outweighs the risk posed by terrorists.

To illustrate, consider the case of the United States and Saudi Arabia throughout the 1990s. The United States suspected that Saudi Arabia maintained ties to al Qaeda and supported the group through various charitable organizations. The Saudis denied any connection with al Qaeda and continued to profess cooperation with American counterterrorist efforts. However, given Saudi Arabia's extensive intelligence network and vast oil riches, it seemed inconceivable that al Qaeda could draw on Saudi charities without the knowledge of the kingdom's leadership. Presumably, since Saudi Arabia is a high-capacity state $(\beta \rightarrow 2)$, the United States should have identified Saudi Arabia as a sponsor and imposed sanctions. However, if the United States did impose sanctions, the economic damage resulting from this action would have been significant. One scenario might have been an increase in the price of gasoline for American consumers, while another scenario may have involved the Saudis slowing the purchase of American treasuries, leading to a spike in US interest rates. Given these potential consequences, the United States chose to continue fighting al Qaeda without imposing sanctions, despite the strong possibility that the Saudis were enhancing al Qaeda's military power through private channels. ${ }^{20}$ The potential damage from sanctions simply outweighed the cost of fighting a state-sponsored al Qaeda in this case. Formally, governments will avoid imposing sanctions if $\beta>p / \varphi$, indicating that high-capacity states are less likely to face sanctions.

Proposition 2. For sufficiently high-capacity foreign states $(\beta>p / \varphi)$, no sanctions occur and the following strategies and beliefs constitute a perfect Bayesian equilibrium:

1. Sponsor: Attack.

2. Terrorists: $\sim$ Attack.

3. Government: $\sim$ Sanction.

4. Beliefs: $\operatorname{Pr}\{\Omega \mid$ Attack $\}=1 \& \operatorname{Pr}\{\Omega \mid \sim$ Attack $\}=0$.

20. See Byman (2005a, 224-38) for an overview of this case.
Proof. See the appendix.

Taken together, these results indicate that we are empirically unlikely to observe sanctions against weaker foreign states and against very powerful foreign states. This leaves us with foreign states with intermediate levels of state capacity $(k / p<\beta<p / \varphi)$. In these cases, governments will face a more difficult challenge in determining the type of foreign supporter they are facing. The foreign state's capacity is high enough that sponsoring a terrorist group is possible but is too low to determine conclusively that terrorists would not operate without sponsorship. To illustrate, consider that the Pakistani government is strong enough to bolster the Taliban's operations but does not appear dominant in the FATA, leaving open the possibility that the Taliban could operate without sponsorship. This intermediate level of state capacity therefore creates considerable difficulty in assessing the relationship between the foreign state and its terrorists.

Since the government cannot determine the foreign state's type in the intermediate range and the government prefers to sanction sponsors while cooperating with hosts, there is an incentive for sponsors to misrepresent themselves as hosts. We therefore see a strategic logic for why foreign states with intermediate levels of state capacity sponsor terrorism covertly and seek plausible deniability. If a sponsor were to support terrorism openly, it would invite a punitive response (such as sanctions) that may undermine terrorists' ability to accomplish their objectives. However, if governments believe that a true sponsor is actually a host, the sponsor could use the gains from continuing its economic transactions with the government to fuel greater terrorism and improve the group's probability of success. Interestingly, this suggests that most effective sponsors of terrorism are those states that cannot be definitively classified as sponsors. ${ }^{21}$

The case of US relations with Pakistan illustrates this logic. On the surface, the Pakistani government appeared cooperative with the US efforts to disarm the Taliban and al Qaeda. The United States therefore supplied Pakistan with billions in economic and military aid. We may never know what exactly Pakistan did with this aid since it is impossible to know if the governments of Musharraf or Zardari were truly hosts or sponsors. However, we do see logically that if Pakistan sponsored the Taliban, keeping this behavior secret would have been incredibly beneficial. Pakistan could transfer a portion of the flow of economic and military goods to the Taliban, which in turn would improve their ability to fight the Americans. However, if the United States

21. This might explain part of the reason why Saddam Hussein refused to support al Qaeda. See Bapat et al. (2007) for a further discussion. 
came to believe that Pakistan was sponsoring the Taliban, it would impose sanctions and cut off the flow of economic resources, which in turn would make the task of supporting terrorists more difficult. Pakistan therefore had a strategic incentive to continue denying its cooperation with both the Taliban and al Qaeda, a claim that became dubious once bin Laden's Abbottabad compound was discovered less than a mile from a prestigious Pakistani military academy.

Let us consider the players' behavior if the foreign state is in the intermediate range of state capacity. Since $G$ cannot determine the foreign state's type using $\beta$, it chooses its strategy on the basis of its posterior beliefs. Government $G$ is indifferent between cooperating with the foreign state and imposing sanctions if $G$ 's belief that the foreign state is a sponsor is equal to

$$
\Omega^{*}=\left[p+(\beta-1) \beta^{2} \varphi\right] /\left[p\left(1-\beta+\beta^{2}\right)\right] .
$$

Although $G$ is uncertain about the foreign state's type, $G$ updates $G^{\prime}$ 's beliefs by observing if terrorist attacks materialize. It imposes sanctions if $\Omega^{\prime}>\Omega^{*}$ and does not sanction if $\Omega^{\prime} \leq \Omega^{*}$.

In the first case, where the government has a stronger prior that the foreign state is a sponsor $\left(\Omega>\Omega^{*}\right)$, the government's pure strategy is to sanction, which deters sponsors from supporting terrorists. If the terrorists operate from a host state, the sanctions would encourage the terrorists to continue their violence. However, since the government recognizes that sponsors should not attack if $\Omega>$ $\Omega^{\star}$, governments will update that the terrorists are operating autonomously from host states. The bombing of the Indian Parliament building in New Delhi illustrates this case. Much of the Indian Parliament presumed that Pakistan sponsored the attacks on the basis of its history of supporting Kashmiri militants and Musharraf's ties with the ISI. Yet, if Musharraf knew that India would blame him for the attacks, why would he sponsor them? The alternative argument, outlined by the Pakistanis, was that the militants operated autonomously and attempted to aggravate tensions between the rivals. Indian Prime Minister Atul Vajpayee appeared to accept this explanation following $\mathrm{Mu}$ sharraf's promise to rein in these groups, and tensions eased into the following year. However, if Musharraf was misrepresenting himself as a host when he was actually a sponsor, Vajpayee's refusal to impose sanctions increased the power of the Pakistani-supported terrorist groups operating against India. We therefore see that while imposing sanctions in response to terrorist violence encourages attacks from host states, an outright refusal to impose sanctions encourages state-sponsored attacks. This indicates that there is no pure strategy for this set of cases. Instead, the solution is char- acterized by a semiseparating strategy in which the government imposes sanctions with some positive probability, represented by the solid line in the intermediate range of $\beta$ in figure 2 .

Proposition 3. For intermediate-capacity foreign states $(k / p \leq \beta \leq p / \varphi)$, sanctions occur with some positive probability. If $\Omega>\Omega^{\star}$, the following strategies and beliefs constitute a semiseparating perfect Bayesian equilibrium: ${ }^{22}$

1. Sponsor: Attack with probability $\mu$ and $\sim$ Attack with probability $1-\mu$.

2. Terrorists: Attack.

3. Government: Sanction with probability $q$ and $\sim$ Sanction with probability $1-q$.

4. Beliefs: $\operatorname{Pr}\{\Omega \mid$ Attack $\}=\Omega^{*} \& \operatorname{Pr}\{\Omega \mid \sim$ Attack $\}=1$.

Proof. See the appendix.

On the other hand, if the government's prior that the foreign state is a sponsor is weaker $\left(\Omega \leq \Omega^{*}\right)$, G should refuse to impose sanctions in response to terrorist attacks. This should deter autonomous terrorists from attacking but also encourages state-sponsored groups to attack. Therefore, if the government observes terrorist violence, it may infer that the terrorists receive state sponsorship. The government will then switch its strategy and impose sanctions. India and Pakistan again provide an example of this case: relations between the two countries appeared to thaw following the crisis of late 2001. The Indian government believed that Pakistan was honoring its commitment to crack down on Kashmiri terrorists. However, in December 2008, LeT terrorists engaged in two spectacular attacks against two hotels in Mumbai. The Pakistani government again denied complicity and claimed that various "nonstate actors" attempted to foment another crisis. However, in contrast to 2001, India was unwilling to accept Pakistan's explanation. Since 2002, India and Pakistan were pursuing what was known as the "composite dialogue," which represented final negotiations over territorial disputes and efforts to bolster trade. The two sides opened lines of transportation between their territories and initiated efforts to bolster economic cooperation. Following the attacks, India suspended the negotiations over the composite dialogue,

22. In part 1 ,

$$
\mu=\left[\left(p+\beta^{2} \varphi(\beta-1)\right)(\Omega-1)\right] /[(\beta-1)(\beta \varphi-p) \beta \Omega] .
$$

In part 3, $q=(\beta p-k) /(\varphi+p)$. 
258 / Sanctions and Terrorism Navin A. Bapat et al.

Table 2. Empirical Expectations as a Function of the Foreign State's Capacity $(\beta)$

\begin{tabular}{ll}
\hline Foreign State Capacity & \multicolumn{1}{c}{ Empirical Expectation } \\
\hline Weak & $G$ does not impose sanctions \\
Moderate & $G$ imposes sanctions with some positive probability in mixed strategies \\
Strong & $G$ does not impose sanctions \\
\hline
\end{tabular}

thereby ceasing the growth in Indo-Pakistani economic ties. India claimed that it was unable to continue good-faith negotiations with Pakistan given the Mumbai events. As a result, trade and investment between the two states fell precipitously in the following year.

Although India was initially willing to give Pakistan the benefit of the doubt, the government updated its beliefs after observing the Mumbai attacks and conducting a subsequent investigation. India soon accused Pakistan of some complicity in the attacks and suspended economic cooperation. However, if Pakistani officials were telling the truth and the terrorists did indeed operate independently, India's suspension of the composite dialogue inadvertently strengthened the LeT. On the other hand, if the attacks were $\mathrm{Pa}$ kistani inspired and India did nothing, the refusal to impose sanctions would encourage greater state sponsorship. We therefore see that the solution is again characterized by a semiseparating strategy in which the government imposes sanctions with some positive probability, represented by the dashed line in the intermediate range of $\beta$ in figure 2 .

Proposition 4a. For intermediate-capacity foreign states $\left(k / p<\beta<p / c_{T}\right)$, no sanctions occur and the following strategies and beliefs constitute a pooling perfect Bayesian equilibrium:

1. Sponsor: Attack.

2. Terrorists: Attack.

3. Government: $\sim$ Sanction.

4. Beliefs: $\operatorname{Pr}\{\Omega \mid$ Attack $\}=\Omega$.

Proof. See the appendix.

Proposition 4b. For intermediate-capacity foreign states $\left(p / c_{T}<\beta<p / \varphi\right)$, sanctions occur with some positive probability. If $\Omega \leq \Omega^{\star}$, the following strategies and beliefs constitute a semiseparating perfect Bayesian equilibrium: ${ }^{23}$

\footnotetext{
23. In part 2,$$
\sigma=[\beta \Omega(\beta-1)(\beta \varphi-p)] /\left[\left(p+\beta^{2} \varphi(\beta-1)\right)(-1+\Omega)\right] .
$$

In part $3, j=\left[(\beta-1)\left(\beta c_{T}-p\right)\right] / p$
}

1. Sponsor: Attack.

2. Terrorists: Attack with probability $\sigma$ and $\sim$ Attack with probability $1-\sigma$.

3. Government: Sanction with probability $j$ and $\sim$ Sanction with probability $1-j$.

4. Beliefs: $\operatorname{Pr}\{\Omega \mid$ Attack $\}=\Omega^{\star} \& \operatorname{Pr}\{\Omega \mid \sim$ At$\operatorname{tack}\}=\Omega$.

Proof. See the appendix.

Table 2 outlines the government's equilibrium behavior and presents our empirical expectations. The model predicts that governments are unlikely to sanction if the foreign state's capacity is low, given that these states are unlikely to be sponsors. Similarly, governments are unlikely to sanction foreign states with high capacity, either because these states are deterred from sponsorship or because the economic relationship is too valuable to sever. In the intermediate range, where $G$ adopts a mixed strategy, there is some positive probability that the government will respond to terrorist violence by imposing sanctions. This probability increases as the foreign state's capacity increases from weak to moderate but drops off once the foreign state becomes too powerful. Interestingly, the model predicts that there is a low overall likelihood of the imposition of sanctions but that it does maximize against states with intermediate state capacity. These states are strong enough to be able to influence the outcome of the terrorist campaign but are not so strong that severing the economic relationship would cause significant damage to the sanctioning government.

H1. Governments are more likely to respond to transnational terrorist campaigns with sanctions if the foreign state exhibits a moderate level of state capacity.

From the model, we gain several insights into how economic sanctions affect transnational terrorist campaigns. First, we see that sanctions are unlikely to be imposed against weaker states. These states do not have the power to strengthen terrorists through sponsorship. Additionally, sanctions will effectively make weak states even weaker and produce conditions that are more favorable to transnational terrorists. We therefore see that the foreign state's capacity provides information about its type to governments facing 
transnational terrorism. On the other hand, foreign states that are very powerful are also likely to avoid sanctions. The economic ties to these states are so valuable that governments will risk conflicts with state-sponsored terrorists over severing lucrative economic transactions. This may explain why countries such as the United States and the former USSR, both of which actively sponsored terrorist groups, never faced sanctions from any of their targets.

The more interesting cases are the foreign supporters with intermediate levels of capacity. Here, because the foreign state is powerful enough to be able to sponsor terrorism but not powerful enough to control the group fully, there is uncertainty about its type. The model indicates that in many cases, sponsors mimic the behavior of hosts, suggesting that these moderately powerful states have the strongest incentive to sponsor terrorism. On the other hand, because sponsorship can provoke sanctions, terrorists also have incentives to provoke governments into imposing sanctions to further their objectives. This echoes the argument made by the Pakistanis following the Mumbai attacks, when they stated that terrorists sought to create conflict between India and Pakistan. The model suggests that we cannot empirically identify what the "true" relationship between a foreign state and terrorists is in this intermediate category. However, governments are more likely to use sanctions when facing foreign states that exhibit moderate levels of state capacity.

\section{EMPIRICAL ANALYSIS}

A test of hypothesis 1 requires data on a sender government that has enough economic power to impose meaningful sanctions and is targeted by one or more transnational terrorist groups in several foreign states. Theoretically, any state could serve as a sender and impose sanctions against targets suspected of colluding with terrorists. For example, throughout the 1970s, the government of Rhodesia imposed sanctions against Zambia to compel President Kenneth Kaunda into revoking his support for the Zimbabwe African National Union. Although these types of sanctions are rare according to the TIES data set, we do see that the United States is identified as the primary sender in 20 out of 31 cases of sanctions imposed to "terminate support for non-state actors" and/or "deter or punish drug trafficking practices" (64.5\%). Interestingly, TIES also identifies the United States as a sender in almost half of the sanctions episodes from 1945 to 2005. In sum, the United States is the most frequent sender of sanctions, is one of the few states to use this tactic in combating transnational terrorists, and accounts for a large enough portion of international economic activity to be able to damage sanctioned states' economies. We therefore limit the analysis to cases in which the United States serves as a sender. We identify transnational terrorist challenges to the United States by focusing on attacks against US interests abroad or transnational attacks within US soil. This definition excludes domestic terrorists such as the Ku Klux Klan or the Black Panthers.

The next step is to determine which countries are considered potential target states for American sanctions. We identify targets as any state where terrorist attacks against US interests took place using the Global Terrorism Database (GTD2). After locating the set of transnational attacks in the GTD where the United States was an attack target from 1970 to 2005 (4,729 incidents), we dropped 690 cases in which the perpetrating group was unknown, was unclear, or was a domestic group within the United States. This list of potential targets was next merged with TIES data to create a dyadic data set consisting of the United States and each potential target in the period 1970-2005. Since US efforts against transnational terrorists focus primarily on the developing world, we dropped the Group of 8 countries, the set of NATO allies, and other major powers as potential target states. The final data set consists of 85 target states and 3,725 dyad years from 1970 to 2005 .

\section{Dependent variable}

The dependent variable is whether or not the United States imposes sanctions against one of the target states in the sample in a given year. In coding this variable, the first question is what types of sanctions to focus on. As the model suggests, states can rarely craft sanctions for the specific purpose of punishing state sponsors, because the latter have the incentive to misrepresent. However, it is possible for the United States to use other types of sanctions to punish countries with potential terrorist ties. For example, in the mid1990s, the United States imposed sanctions against Syria in response to its drug-trafficking practices, despite the fact that Syria has rarely been mentioned as a critical state in the international drug trade. In total, we identify 164 impositions against target states in this period, representing $4.6 \%$ of the observations.

\section{Explanatory variables}

Hypothesis 1 states that the sender should be more likely to impose sanctions against targets with intermediate levels of capacity compared to targets that exhibit very low or high levels of capacity. We capture this curvilinear relationship by squaring several measures of state capacity from the current literature. First, we use the target state's per capita GDP score, expressed in thousands of constant 2005 US dollars, from the World Development Indicators. Since this measure is often criticized (Hendrix 2010), we also include two indicators drawn from the relative political reach (RPR) index 
(Kugler and Tamen 2012). ${ }^{24}$ This index seeks to capture the capacity of the state to mobilize its own population by weighing factors such as the share of educated population, the share of social security taxes over GDP, and the unemployment rate. Effective governments are able to mobilize resources necessary for implementation of their policy agenda, while ineffective governments fail. Therefore, the political reach index incorporates a range of social and economic measures that reflect the degree to which the government is present in citizens' regular activities. Each capacity variable with its squared term is included in a separate model.

We also include several control variables in the statistical models. First, we use UN voting affinity data to control for the similarity of foreign policy preferences (Strezhnev and Voeten 2013). For every country selected into the sample, we include $s$-scores between this country and the United States in a given year. Second, we include a measure of trade interdependence between the United States and the target state using the share of US exports to each country divided by US GDP and US imports from each country as a share of US GDP (Barbieri and Keshk 2012). We further control for the target's regime type by including the target state's polity score and a dummy variable indicating if the country transitioned from democracy to autocracy (Cheibub, Gandhi, and Vreeland 2010). We also use Correlates of War data on intrastate wars to control for the existence of a domestic conflict in the country where the US interests were attacked (Sarkees and Wayman 2010). Finally, we include a measure of the target's population size from the World Development Indicators to capture the target's internal heterogeneity.

Finally, we control for the number of attacks against US interests in each country in the sample. If sanctions simply follow terrorist attacks, we should expect that the more attacks the United States experiences in a country, the higher the probability of US sanctions will be. However, if our argument is correct, sanctions should not depend on the number of attacks. To test this implication of the model, we construct a count variable for the number of yearly attacks against US interests in a given country.

24. The political reach measures are constructed on the basis of estimates from two models: for the first measure (RPRw), the dependent variable is the ratio of activity rate to population; for the second (RPRe), the dependent variable is the ratio of economically active population to population. The key regressors in these models are education, young population, social security, urbanization, population, GDP per capita, bureaucracy, and, in the second model only, unemployment. For more information on these measures and the data, see Arbetman-Rabinowitz et al. (2013). Our results also hold if we use targets' Composite Index of National Capacity scores.

\section{Method}

Given that we use a pooled cross-sectional time-series data set with a binary dependent variable, we test the hypothesis using a logit model with standard errors clustered on the target states. We control for temporal dependence using the cubic polynomial approach suggested by Carter and Signorino (2010): we include a count variable for years without attacks $(t), t^{2}$ and $t^{3}$ in all specifications. Our expectation is that the coefficient on the state capacity measure will be positive, whereas the coefficient on the squared state capacity term will be negative. This captures our prediction that the probability of sanctions maximizes in the intermediate range of capacity but subsequently falls as state capacity becomes very large.

\section{RESULTS}

Table 3 presents the results from the statistical tests. Each of the measures for state capacity along with their squared terms are significant and in the anticipated directions in each of the four models. ${ }^{25}$ The observation that each of the variables capturing state capacity leads to a similar statistical relationship strengthens the general support for hypothesis 1 . Interestingly, the number of attacks against US interests in potential target countries does not have a statistically significant effect on the likelihood of sanctions in any of the models. This supports our expectation that when the United States faces challenges from transnational terrorists, its response depends on the strength of the foreign state rather than on the harm caused to US interests. ${ }^{26}$

Figures 3 and 4 illustrate the curvilinear relationship between sanction imposition and state capacity. The first panel of figure 3 is based on model 1 of table 3 and graphs the predicted effect of a country's per capita GDP on the probability of US sanction imposition when a terrorist at-

25. Recall that our theoretical results suggest that the nonsquared measure of government capacity should have a positive coefficient because foreign states are more likely to be punished by sanctions as their capacity grows from low to moderate levels, as sponsorship becomes more likely. The squared term, on the other hand, should have a negative coefficient because for high capacity levels, the effect of foreign states' capacity on sanction imposition should lessen and then reverse. In more technical terms, our expectation of a nonmonotonic relationship indicates that the coefficient on the squared term should be negative. The nonsquared term, then, should have a positive coefficient to capture the nonmonotonicity because this term determines whether the maximum occurs for capacity values less than or greater than zero, and our capacity measures take only positive values.

26. We used other approaches to accounting for caused harm (e.g., we restricted the sample to attack locations where US citizens were killed), and the results remained largely unchanged. 
Table 3. Sanction Imposition by the United States against States Where Its Interests Have Been Attacked

\begin{tabular}{|c|c|c|c|c|}
\hline & $\begin{array}{c}\text { Model } 1 \\
\text { GDPpc }\end{array}$ & $\begin{array}{c}\text { Model } 2 \\
\ln (\text { GDPpc })\end{array}$ & $\begin{array}{c}\text { Model } 3 \\
\text { RPRw }\end{array}$ & $\begin{array}{c}\text { Model } 4 \\
\text { RPRe }\end{array}$ \\
\hline \multirow[t]{2}{*}{ State capacity } & $.18^{\star *}$ & $2.02^{\star *}$ & $9.03^{* *}$ & $38.60^{* *}$ \\
\hline & $(.06)$ & $(.54)$ & $(3.81)$ & $(12.10)$ \\
\hline \multirow[t]{2}{*}{ State capacity squared } & $-.01^{\star *}$ & $-.10^{* *}$ & $-4.21^{\star *}$ & $-19.03^{* *}$ \\
\hline & $(.00)$ & $(.03)$ & $(1.78)$ & (5.89) \\
\hline \multirow[t]{2}{*}{ No. attacks against US } & -.03 & -.04 & -.04 & -.04 \\
\hline & $(.03)$ & $(.04)$ & $(.03)$ & $(.03)$ \\
\hline \multirow[t]{2}{*}{ Transition to dictatorship } & $1.62^{* *}$ & $1.62^{\star *}$ & $1.49^{* *}$ & $1.45^{\star *}$ \\
\hline & $(.72)$ & $(.72)$ & $(.69)$ & $(.70)$ \\
\hline \multirow[t]{2}{*}{ Polity } & $.05^{\star \star}$ & $.05^{\star *}$ & $.05^{\star \star}$ & $.04^{\star *}$ \\
\hline & $(.02)$ & $(.01)$ & $(.01)$ & $(.01)$ \\
\hline \multirow[t]{2}{*}{$\ln$ (population) } & $.44^{\star *}$ & $.58^{\star \star}$ & $.38^{\star *}$ & $.38^{\star *}$ \\
\hline & $(.09)$ & $(.09)$ & $(.06)$ & $(.07)$ \\
\hline \multirow[t]{2}{*}{ Intrastate war } & $.49^{*}$ & $.53^{*}$ & .28 & .26 \\
\hline & $(.28)$ & $(.28)$ & $(.30)$ & $(.29)$ \\
\hline \multirow[t]{2}{*}{$\ln$ (US exports/GDP) } & .09 & -.01 & .01 & .09 \\
\hline & $(.12)$ & $(.13)$ & $(.14)$ & $(.13)$ \\
\hline \multirow[t]{2}{*}{$\ln$ (US imports/GDP) } & -.06 & -.08 & .06 & -.00 \\
\hline & $(.09)$ & $(.07)$ & $(.10)$ & $(.10)$ \\
\hline \multirow[t]{2}{*}{ UN voting affinity } & -.21 & .09 & .01 & .10 \\
\hline & $(.27)$ & $(.31)$ & $(.30)$ & $(.29)$ \\
\hline \multirow[t]{2}{*}{$t$ (years without attack) } & -.06 & -.04 & -.07 & -.06 \\
\hline & $(.08)$ & $(.08)$ & $(.07)$ & $(.07)$ \\
\hline \multirow[t]{2}{*}{$t^{2}$} & .00 & .00 & .00 & .00 \\
\hline & $(.01)$ & $(.01)$ & $(.01)$ & $(.01)$ \\
\hline \multirow[t]{2}{*}{$t^{3}$} & -.00 & -.00 & -.00 & -.00 \\
\hline & $(.00)$ & $(.00)$ & $(.00)$ & $(.00)$ \\
\hline \multirow[t]{2}{*}{ Constant } & $-10.01^{\star *}$ & $-23.96^{\star *}$ & $-12.24^{\star *}$ & $-26.51^{\star *}$ \\
\hline & (3.15) & $(4.37)$ & $(3.40)$ & $(6.72)$ \\
\hline Observations & 2,570 & 2,570 & 2,829 & 2,829 \\
\hline Log likelihood & -476.64 & -475.98 & -509.84 & -508.05 \\
\hline Wald test & 128.86 & 167.33 & 155.80 & 140.39 \\
\hline
\end{tabular}

Note. Logit models; robust clustered standard errors are in parentheses.

${ }^{*} p<.10$.

${ }^{* *} p<.05$.

tack against US interests has taken place in the country. Both panels of figure 4 show the same effect, but using relative political capacity variables (RPRw and RPRe) instead of GDP per capita as measures of state capacity. Finally, the second panel of figure 3 also shows a nonmonotonic relationship between logged GDP per capita and the likelihood of sanction imposition, based on the results from model 2 in table 3. However, wide confidence intervals for the highest values of the state capacity measure mean that our predictions are less precise in that range. In sum, three out of four models yield robust empirical evidence that the probability of sanction imposition initially increases as a function of increasing target capacity but subsequently falls as the target's capacity reaches higher levels. These results support the predictions of hypothesis 1: the United States is less likely to impose sanctions in cases in which targets exhibit very low state capacity and in cases in which targets exhibit high state capacity. On the other hand, if targets are in the intermediate range, the United States may be unable to determine if they are hosts or sponsors. In these cases, the theoretical model predicts that sanctions may occur in mixed strategies. Our empirical tests demonstrate that the probability of sanctions maximizes in this intermediate category and hence support our expectation that the sender 

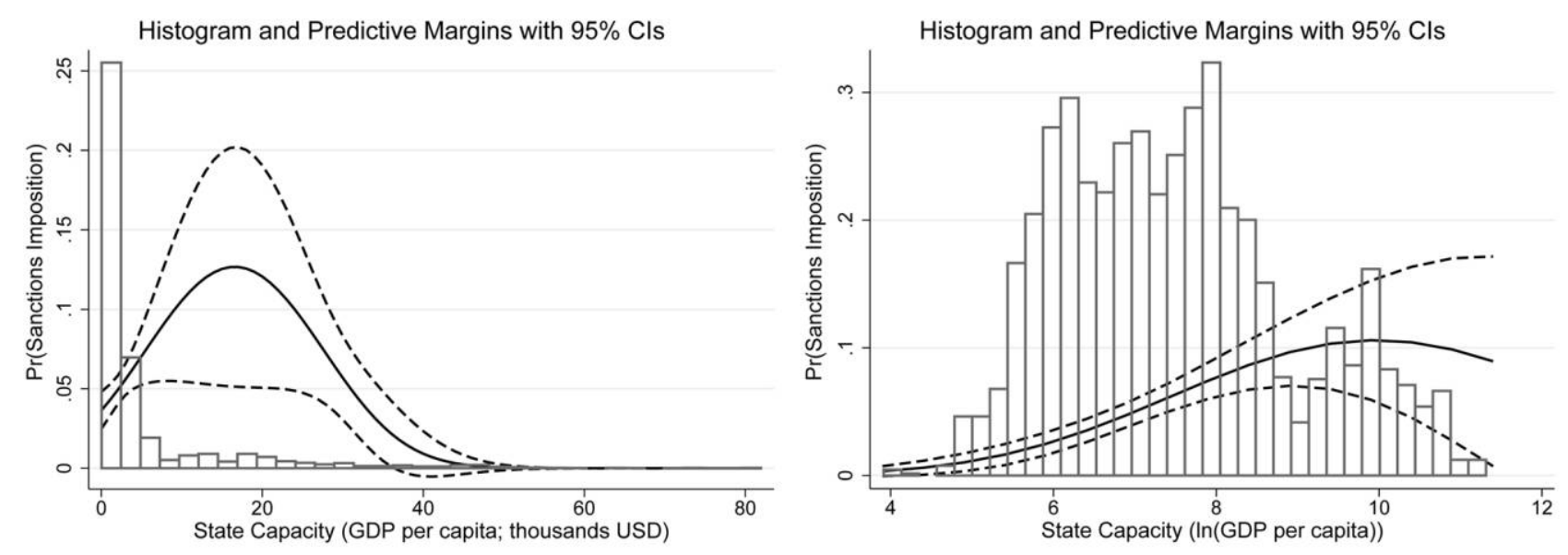

Figure 3. Predicted effects of per capita GDP on sanction probability (models 1 and 2, table 3)

should be more likely to impose sanctions in response to the uncertainty about the target state's actual relationship with the terrorists.

\section{CONCLUSION}

The literature on counterterrorism suggests that states should impose sanctions against known sponsors of terrorism but should engage host states by expanding economic cooperation. This study demonstrates that this strategy creates an incentive for sponsors to misrepresent themselves as host states. Since senders know that all states have incentives to deny sponsoring terrorists but cannot perfectly observe if supporting states are truly sponsors or hosts, governments must use observable information to make inferences about the relationship between foreign states and terrorists. We argue that the key piece of information for senders is the state's capacity: governments can deduce that states with very low levels of capacity are likely to be hosts, whereas states with very high levels of capacity are likely to be sponsors. The key challenge for senders occurs when foreign states have intermediate capacity, which results in an environment of uncertainty about the foreign state's true type. During the "war on terror," experts have often disagreed about whether several intermediate states, such as Pakistan and Yemen, are truly cooperative hosts versus active sponsors. This problem is exacerbated by sponsors' incentives to misrepresent themselves as hosts in order to support terrorism successfully and avoid punishment. We demonstrate formally that this incentive to misrepresent causes governments to impose sanctions against states that exhibit intermediate levels of capacity. Governments impose sanctions as part of a mixed strategy when they are unable to ascertain the true nature of the relationship between foreign states and terrorist groups.
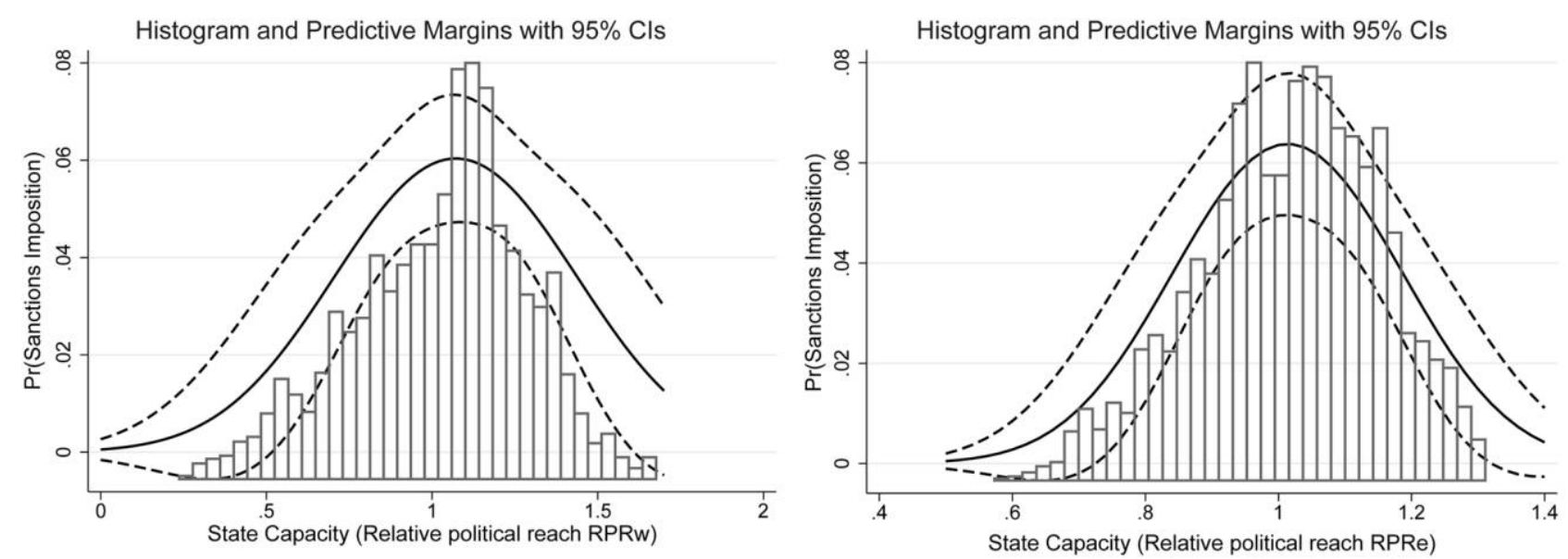

Figure 4. Predicted effects of relative political reach on sanction probability (models 3 and 4, table 3 ) 
This study indicates that the most effective supporters of terrorism are those that can most successfully imitate the behavior of host states. Successful supporters may not appear outwardly hostile, such as Saddam Hussein's Iraq, but should instead appear to be cooperative, such as Musharraf's Pakistan. Second, the model demonstrates that sanctions alone cannot compel sponsors to abandon terrorists, nor can sanctions convince hosts to "do more" in undermining the group's activities. Sanctions simply aim to undermine the group's ability to draw resources from foreign states, which in turn harms the group's ability to achieve its objectives. This suggests that in terms of measuring whether or not sanctions "work," it is inappropriate to simply examine if a foreign supporter cuts off its terrorist group. Instead, our focus should be on the success of sanctions in undermining terrorist campaigns and terrorist groups' ability to accomplish their strategic objectives.

\section{ACKNOWLEDGMENTS}

We would like to thank Cliff Morgan, Cooper Drury, Songying Fang, Ric Stoll, Dina Zinnes, and the participants in the "Economic Sanctions and Political Processes: Going Beyond 'Do They Work?'” workshop for their very helpful comments.

\section{REFERENCES}

Aksoy, Deniz, and David B. Carter. 2012. "Electoral Institutions and the Emergence of Terrorist Groups." British Journal of Political Science 1:1-24.

Allen, Susan H. 2005. "The Determinants of Economic Sanctions Success or Failure." International Interactions 31 (2): 117-38.

Arbetman-Rabinowitz, Marina, Ali Fisunoglu, Jacek Kugler, Mark Abdollahian, Kristin Johnson, Kyungkook Kang, and Zining Yang. 2013. "Replication Data for: Relative Political Capacity Dataset." Transresearch Consortium, V4. http://thedata.harvard.edu/dvn/dv/rpc/faces/study/Study Page.xhtml?globalId = hdl:1902.1/16845 (accessed November 15, 2013).

Bapat, Navin A. 2012. "Understanding State Sponsorship of Militant Groups." British Journal of Political Science 42 (1): 1-29.

Bapat, Navin A., Daniel Ertley, Chansonette Hall, and Mark Lancaster. 2007. "Perfect Allies? The Case of Iraq and al Qaeda." International Studies Perspectives 8 (3): 272-86.

Bapat, Navin A., Tobias Heinrich, Yoshi Kobayashi, and T. Clifton Morgan. 2013. "The Determinants of Sanctions Effectiveness: Sensitivity Analysis Using New Data.” International Interactions 39 (1): 79-98.

Bapat, Navin A., and T. Clifton Morgan. 2009. "Multilateral versus Unilateral Sanctions Reconsidered: A Test Using New Data.” International Studies Quarterly 53 (4): 1075-94.

Barbieri, Katherine, and Omar Keshk. 2012. "Correlates of War Project Trade Data Set Codebook, Version 3.0.” http://correlatesofwar.org (accessed November 15, 2013).

Byman, Daniel. 2005a. Deadly Connections: States That Sponsor Terrorism. Cambridge: Cambridge University Press.
Byman, Daniel. 2005b. "Passive Sponsors of Terrorism." Survival 47 (4): 117-44.

Byman, Daniel, Peter Chalk, Bruce Hoffman, William Rosenau, and David Brannan. 2001. Trends in Outside Support for Insurgent Movements. Santa Monica, CA: RAND.

Carter, David. 2015. “The Compellence Dilemma: International Disputes with Violent Groups.” International Studies Quarterly 59 (3): 46176.

Carter, David B., and Curtis S. Signorino. 2010. "Back to the Future: Modeling Time Dependence in Binary Data.” Political Analysis 18 (3): 271-92.

Cheibub, José Antonio, Jennifer Gandhi, and James Raymond Vreeland. 2010. "Democracy and Dictatorship Revisited." Public Choice 143 (2): 67-101.

Collier, Paul, and Anke Hoeffler. 2005. "Resource Rents, Governance, and Conflict.” Journal of Peace Research 49 (4): 625-33.

Conrad, Justin. 2011. "Interstate Rivalry and Terrorism: An Unprobed Link." Iournal of Conflict Resolution 55 (4): 529-55.

DeGennaro, Ramon P. 2005. "Market Imperfections.” Journal of Financial Transformation 14:107-17.

Drezner, Daniel. 2003. "The Hidden Hand of Economic Coercion." International Organization 57 (3): 643-59.

Drury, A. Cooper. 1998. "Revisiting Economic Sanctions Reconsidered." Lournal of Peace Research 35 (4): 497-509.

Enders, Walter, and Gary A. Hoover. 2012. "The Nonlinear Relationship between Terrorism and Poverty." American Economic Review 102 (3): $267-72$.

Fearon, James D. 2004. "Why Do Some Civil Wars Last So Much Longer than Others?" Iournal of Peace Research 41 (3): 275-301.

Fearon, James D., and David Laitin. 2003. "Ethnicity, Insurgency, and Civil War." American Political Science Review 97 (1): 75-90.

Findley, Michael, James Piazza, and Joseph Young. 2012. "Games Rivals Play: Terrorism in International Rivalries." Lournal of Politics 74 (1): 235-48.

Greenwald, Bruce C., and Joseph E. Stiglitz. 1993. "Financial Market Imperfections and Business Cycles." Quarterly Journal of Economics 108 (1): 77-114.

Hegre, Havard, and Nicholas Sambanis. 2006. "Sensitivity Analysis of Empirical Results on Civil War Onset." Iournal of Conflict Resolution 50 (4): 508-35.

Hendrix, Cullen S. 2010. "Measuring State Capacity: Theoretical and Empirical Implications for the Study of Civil Conflict.” Lournal of Peace Research 47 (3): 273-85.

Hufbauer, Gary Clyde. 2001. "Using Sanctions to Fight Terrorism." Policy Brief 01-11, Peterson Institute for International Economics, Washington, DC.

Hufbauer, Gary Clyde, Jeffrey J. Schott, Kimberly Anne Elliott, and Barbara Oegg. 2007. Economic Sanctions Reconsidered. Washington, DC: Peterson Institute for International Economics.

Kugler, Jacek, and Ronald Tammen. 2012. Performance of Nations. Lanham, MD: Rowman \& Littlefield.

Kydd, Andrew, and Barbara F. Walter. 2002. "Sabotaging the Peace: The Politics of Extremist Violence." International Organization 56 (2): 263-96.

Lacy, Dean, and Emerson Niou. 2004. "A Theory of Economic Sanctions and Issue Linkage: The Roles of Preferences, Information, and Threats." Journal of Politics 66 (1): 25-42.

Li, Quan, and Drew Schaub. 2004. "Economic Globalization and Transnational Terrorism: A Pooled Time-Series Analysis." Lournal of Conflict Resolution 48 (2): 230-58. 
264 / Sanctions and Terrorism Navin A. Bapat et al.

Marinov, Nikolay. 2005. "Do Economic Sanctions Destabilize Country Leaders?" American Journal of Political Science 49 (3): 564-76.

McGillivray, Fiona, and Allan Stam. 2004. "Political Institutions, Coercive Diplomacy, and the Duration of Economic Sanctions." Journal of Conflict Resolution 48 (2): 154-72.

McLean, Elena V., and Taehee Whang. 2010. "Friends or Foes? Major Trading Partners and the Success of Economic Sanctions." International Studies Quarterly 54 (2): 427-47.

Morgan, T. Clifton, Navin A. Bapat, and Valentin Krustev. 2009. "The Threat and Imposition of Economic Sanctions, 1971-2000.” Conflict Management and Peace Science 26 (1): 92-110.

Morgan, T. Clifton, and Anne C. Miers. 1999. "When Threats Succeed: A Formal Model of the Threat and Use of Economic Sanctions." Paper presented at the annual meeting of the American Political Science Association, Atlanta.

Morgan, T. Clifton, and Valerie L. Schwebach. 1997. "Fools Suffer Gladly: The Use of Economic Sanctions in International Crises." International Studies Quarterly 42 (1): 27-50.

Nooruddin, Irfan. 2002. "Modeling Selection Bias in Studies of Sanctions Efficacy.” International Interactions 28 (1): 59-75.

Pape, Robert A. 1997. "Why Economic Sanctions Do Not Work." International Security 22 (2): 90-136.
Piazza, James A. 2008. "Incubators of Terror: Do Failed and Failing States Promote Transnational Terrorism?” International Studies Quarterly 52 (3): 469-88.

Salehyan, Idean. 2009. Rebels without Borders. Ithaca, NY: Cornell University Press.

Sarkees, Meredith Reid, and Frank Wayman. 2010. Resort to War: 18162007. Washington, DC: CQ Press.

Schultz, Kenneth. 2010. "The Enforcement Problem in Coercive Bargaining: Interstate Conflict over Rebel Support in Civil Wars.” International Organization 64 (2): 281-312.

Smith, Alastair. 1995. "The Success and Use of Economic Sanctions." International Interactions 21 (3): 229-45.

Strezhnev, Anton, and Erik Voeten. 2013. United Nations General Assembly Voting Data. Version 5 (accessed June 3, 2014).

Wagner, R. Harrison. 1988. "Economic Interdependence, Bargaining Power and Political Influence." International Organization 42:461-82.

Weinstein, Jeremy. 2007. Inside Rebellion: The Politics of Insurgent Violence. Cambridge: Cambridge University Press.

World Bank. 2010. Investing across Borders: Indicators of Foreign Direct Investment Regulation in 87 Countries. Washington, DC: Investment Climate Advisory Services. http://iab.worldbank.org/ /media/FPDKM /IAB/Documents/IAB-report.pdf (accessed November 15, 2013). 